\title{
Results of Splitting the Application of Nitrogenous Fertilizers to Pangola Grass (Digitaria decumbens)
}

\section{Rivera Brenes ${ }^{1}$}

\section{INTRODUCTION}

In areas like Puerto Rico with almost 12 months of grazing season it is a common pasture-management practice to divide the total fertilizer to be applied per year into several portions to obtain maximum response.

We know that fertilization after each harvest is necessary for maximum yield of soiling grasses. But this is not the case when the grasses are grazed. Dividing the total amount to apply into as many portions as is economically feasible is recommended for sandy soils from which fertilizer leaches out fast. In heavy soils, like most of those in Puerto Rico, it is probably not necessary to divide the yearly fertilizer in too many portions for maximum response and economy. The results of an experiment on this matter are reported in this paper.

\section{LITERATURE REVIEW}

Research on fertilization and fertilizer management is very extensive. Innumerable recommendations are made for pastures, and investigators are in agreement on the fact that the fertilizer, principally nitrogen, should be applied in more than one portion during the pasture season. $(1)^{2}$ Soil texture is important in determining the number of applications to be made during the year. As an example we have the recommendation made for sandy soils to apply fertilizer, principally nitrogen, in several portions to prevent excessive losses by leaching.

Not much work has been done in Puerto Rico on fertilizer management. Silva (5), in an experiment simulating grazing came to the conclusion that dividing the total amount of fertilizer into four applications, that is, an application every 3 months, is best for securing maximum yield. Of course, no animals were grazing and trampling on the pastures, a factor of considerable importance which affects yields.

\section{PROCEDURE}

The experiment was established in a Fajardo clay in the main Station farm located at Río Piedras. Rainfall varies from 70 to 100 inches a year in this section. The test consisted of a block design, each block 3 acres in size, and 1 acre for each treatment. The treatments were randomized ac-

${ }^{1}$ Head Animal Husbandry Department, Agricultural Experiment Station, University of Puerto Rico, Río Piedras, P.R.

2 Italic numbers in parentheses refer to Literature Cited, p. 174. 
cordingly and consisted of 3 acres of Pangola grass to which the total nitrogen fertilizer for the year was applied in three portions, one portion every 4 months; 3 acres of Pangola grass to which the same total amount of nitrogen fertilizer per year was applied in four portions, one every 3 months: and 3 acres of a mixture of Pará grass and tropical kudzu with no nitrogen application at all. This legume-grass mixture was used as a check because with it we had a pasture with a natural nitrogen supply, known to have a carrying capacity of nearly one standard dairy cow-day $(3,4)$.

Three hundred and sixty pounds of nitrogen in ammonium sulfate per acre per year was applied to the Pangola plots and an annual application of 200 pounds of $\mathrm{P}_{2} \mathrm{O}_{5}$ and 400 pounds of $\mathrm{K}_{2} \mathrm{O}$ was applied to all plots.

Dairy heifers weighing from 300 to 400 pounds at the start were used and the put-and-take system was followed. The test animals were retained in the experiment until they were of breeding age, between 18 to 20 months old and weighing about 800 pounds.

The heifers were weighed for 3 consecutive days at the start, then monthly. The number of heifers per acre fluctuated between two and four according to the amount of forage available. The idea was that all forage be consumed but overgrazing and excess trampling be avoided. Each acre was divided in three paddocks for rotation.

Shade, water, and mineralized salt was provided at each plot.

Yield was measured in T.D.N. per acre, using the conversion factors recommended by the Pasture Research Committee (6).

The experiment lasted for 911 consecutive days.

\section{RESULTS AND DISCUSSION}

The results of the experiment are presented in table 1, showing average T.D.N. yield, average daily T.D.N. yield, and carrying capacity per acre per treatment for the duration of the experiment.

No significant differences were found between treatments, indicating that there is no need to apply the yearly total nitrogen to this heavy soil in more than three portions. This, of course, will provide a saving to the farmer and especially those that cannot use machinery for that practice.

Other factors not considered, the Pará grass-kudzu mixture on which no nitrogen was used had the same performance as Pangola grass, without the expense of using the nitrogen fertilizer. This result was obtained previously $(3,4)$. But much care has to be taken to prevent the disappearance of the kudzu in the mixture. The trampling of three heifers per acre was detrimental to the kudzu in the mixture, and we were forced to keep only two heifers on each acre most of the time. Of course, the gains in weight compensated for the number. Really the farmers need pasture grasses that are easy to manage like Pangola grass. 
During the course of the test weeds proved troublesome in all plots, especially two important ones, those growing Venezuela grass (Paspalum fasciculatum) and Horquetilla grass ( $P$. conjugatum). This probably reduced yields somewhat. Two herbicides were used successfully, 2-4D and C.M.U. They were applied to the plots after the heifers were rotated.

\section{SUMMARY AND CONCLUSIONS}

An experiment to determine the effects of applying the total yearly nitrogen fertilizer to Pangola grass pasture in a heavy soil in three and in four portions was carried out. A mixture of Pará grass and tropical kudzu with no nitrogen applications was used as check. Growing dairy heifers were used to measure differences, and the put-and-take system was followed, so that all the roughage was consumed from the plots. Equal amounts of

TABLE 1.-Average T.D.N. yield, average daily T.D.N. yicld, and carrying capacity per acre per treatment for the 911 days of the experiment with Pangola grass

\begin{tabular}{c|c|c|c|c}
\hline Grass & $\begin{array}{c}\text { Average T.D.N. } \\
\text { yield per acre }\end{array}$ & $\begin{array}{c}\text { Average daily } \\
\text { T.D.N. yield }\end{array}$ & $\begin{array}{c}\text { Carrying capacity } \\
\text { for dairy cowt }\end{array}$ & $\begin{array}{c}\text { Carrying capacity } \\
\text { for beef cow }^{2}\end{array}$ \\
\cline { 1 - 2 } Pangola 3 & Posuds & Pounds & Coso-days & Cow-days \\
Pangola 4 & $12,149.50$ & 13.33 & 0.83 & 1.11 \\
Pará/kudzu & $13,298.90$ & 14.60 & .91 & 1.21 \\
& $11,503.54$ & 12.63 & .79 & 1.05 \\
\hline
\end{tabular}

116 pounds of T.D.N. = standard dairy cow-day.

212 pounds of T.D.N. = standard beef cow-day.

phosphorus $\left(\mathrm{P}_{2} \mathrm{O}_{5}\right)$ and potash $\left(\mathrm{K}_{2} \mathrm{O}\right)$ were applied annually to all the pastures.

No statistical differences were found between treatments, indicating that it is probably not necessary to split the total of nitrogen fertilizer into more than three portions in a heavy soil like the Fajardo clay in which the experiment was established. Not taking other management factors into consideration the mixtures of Pará grass and kudzu performed as well as Pangola grass.

\section{RESUMEN Y CONCLUSIONES}

Se llevaron a cabo experimentos para determinar los efectos de aplicar el total del abono nitrogenado por año a pastos de Pangola, en tres y cuatro porciones, en terreno pesado. Un pasto de malojillo y Kudzú tropical sin ninguna aplicación de nitrógeno se usó como testigo para la comparación.

Se usaron novillas lecheras para medir las diferencias. Se utilizó el sistema de poner y quitar animales de acuerdo con la cantidad de forraje en las 
parcelas y de manera que todo el forraje disponible pudiera ser consumido por los animales.

Se aplicaron cantidades iguales anuales de fósforo $\left(\mathrm{P}_{2} \mathrm{O}_{5}\right)$ y potasa $\left(\mathrm{K}_{2} \mathrm{O}\right)$ a todas las parcelas.

No se encontraron diferencias estadísticamente significativas entre los tratamientos, lo que indica que es posible no sea necesario dividir la cantidad anual de nitrógeno a aplicarse por cuerda en más de tres porciones en suelo pesado, como el del experimento. Si no se toman en consideración otros factores de manejo se puede decir que la mezcla de malojillo y Kudzú tropical se comportó tan bien como la Pangola.

\section{LITERATURE CITED}

1. Bartholomew, W. V., Fertilizers for Grass in Rotations, Grass: Yearbook of Agriculture 1948, pp. 199-202, USDA, U. S. Government Printing Office, Washington, D. C.

2. Brown, Marion E., The Management of Grazing, Grass: Yearbook of Agriculture 1948, pp. 135-9, USDA, U.S. Government Printing Office, Washington, I.C.

3. Rivera Brenes, L., The utilization of grasses, legumes, and other forages for cattle feeding in Puerto Rico; I, Comparison of Guinea grass, Pará grass, (Malojillo) and a mixture of Pará grass and tropical kudzu as pasture crops, J. Agr. Univ. P.R. 31 (2) 180-9, 1947.

4. - The utilization of grasses, legumes, and other forage crops for cattle feeding in Puerto Rico; II, Comparison of fertilized Guinea grass, Pará grass and tropical kudzu, and tropical kudzu alone as pasture crops, J. Agr. Univ. P.R. 33 (3) 8597, 1949.

5. Silva, S., Intensively managed grass pastures should be fertilized about four times yearly, Research Note No. 38, May 1961, A.R.S., USDA, Soil and Water Cons. Res. Div. in Co-op. with the Agr. Exp. Sta. of the Univ. of P.R.

6. Preliminary report on pasture investigation techniques, Joint Committee of the American Dairy Society of Agronomy, American Dairy Science Association, and American Society of Animal Production, J. Dairy Sci. 26 353-69, $19+3$. 